\title{
DETECTION OF ANDROGEN RECEPTOR INCIDENCE IN GYNAECOLOGICAL CANCERS AND ITS RELEVANCE IN HIGH
} GRADE SEROUS EPITHELIAL OVARIAN CANCERS

Mariam Anjum Ifthikar ${ }^{1}$ Anupama R ${ }^{1}$ D.K.Vijaykumar ${ }^{1}$ Indu R Nair ${ }^{2}$ Anjaly ${ }^{3}$

-Dept Of Gynaecologic Oncolgy,Amrita Institute Of Medical sciences,Kerala,India

2-Dept Of Pathology,Amrita Institute Of Medical sciences,Kerala,India

3 -Dept Of Biostatistics,Amrita Institute Of Medical sciences,Kerala,India

Targeting Androgen receptors (ARs) results in important salutary effects in prostate malignancy. Exploring the impact of hormonal manipulation of AR receptors has not been widely pursued beyond prostate cancer, despite mounting evidence that ARs also participate in the pathogenesis and/or progression of diverse tumors.

This study describes patterns of AR expression in a spectrum of cancers, and the potential to exploit this knowledge in the clinical therapeutic setting.

\section{AIM:}

The aim of this study is to estimate the incidence of expression of androgen receptor in gynaecological cancers and association of expression of androgen receptor status with Stage, Cytoreduction And Progression Free Survival in high grade epithelial ovarian cancers.

\section{METHODS:}

Prospective observational study-20 months duration

Conducted at Amrita Institute of Medical Sciences,South India

September 2016 till June 2018 -99 consecutive gynaecological cancers Data obtained from hospital information system online database.

All patients who are undergoing upfront primary surgery for gynaecological cancers were included.

Exclusion criteria were the ones who underwent NACT or RT upfront,recurrent disease, benign or boderline pathology.

Details of Receptors expression by using immunohistochemical staining for AR,ER,PR is done in the tissue samples. Results were analysed using IBM SPSS version 20.0, Pearson Chi square test was used.

Outcome is correlated with association of androgen receptor status with Stage, Cytoreduction And PFSin high grade epithelial ovarian cancers .

\section{Results:}

In the course of our study, ARs were differently expressed in different histotypes of gynaecological cancers cancer $(n=99)$; AR expression is $45 \%(n=9 / 20)$ of 20 carcinoma endometrium, $9.1 \%(n=1 / 11)$ cases in cervical cancers and $100 \%$ in sarcoma and ovarian cancers $40.6 \%(\mathrm{n}=64)$, more highly expressed in HGSC $61.5 \%(\mathrm{n}=41 / 64)$ but its association with AR is not statistically significant $(\mathrm{p}=0.78)$.

\section{CONCLUSION:}

- An effective and clinically applicable molecular classification of HGSC can be grouped in our cohort based on ER,PR and AR receptor status

This study describes patterns of AR expression in a spectrum of gynaecological cancers .

- There is No statistical significant association of androgen receptor positivity in high grade serous cancers with Stage,Cytoreduction And Progression Free Survival.

- In PR positive receptors there is statistically significane with younger age and recurrence, thereby the potential to exploit this knowledge in the clinical therapeutic setting

1.Nodin B, Zendehrokh N, Brandstedt J,et al .Increased androg en receptor survival. J Ovarian Res. 2010(3):14

2.Zheng Feng1,2,*, Hao Wen1,2,*, Rui Bi2,3,*, et al .A clinically applicable molecular classification for high-grade serous ovarian cancer based on hormone receptor expression2016 May 16;(4) 6:25408 www.nature.com/scientificreports
Of note, all of the HGSC samples AR expression was associated with neither stage,cytoreduction of EOC nor progression free/overall survival. AR-positivity was associated with improved overall survival, and AR negativity was associated with recurrence but not reaching a statistical significance.

Association between the presence of Progesterone receptor and age group was found to be statistically significant.PR was present in $66.7 \%$ of cases $<50$ years of age group and $34.6 \%$ of cases $>50$ years of age and the difference was statistically significant $(\mathrm{p}$ value $=0.04)$.

Association between the absence of Progesterone receptor and recurrence group was found to be statistically significant.PR was absent in $33.3 \%$ of recurrence and in $6 \%$ of cases PR was positive and difference was statistically significant. $(\mathrm{p}$ value $=0.05$ )

Table 1: Distribution Of Androgen Receptor, Estrogen Receptor ,Progesterone Receptor Expressio Profiles Various Studies

ovarian Cancers Tale 3. Association Of AR With Gynaecological Cancers in The Study Population

作

Assiation Of AR With I And Type II Ovar

\begin{tabular}{|c|c|c|c|c|}
\hline $\begin{array}{l}\text { SEX } \\
\text { STEROID } \\
\text { HORMON } \\
\text { E }\end{array}$ & $\begin{array}{c}\text { Zheng } \\
\text { Feng et al } \\
\text { [7] }\end{array}$ & $\begin{array}{c}\text { Hao wen } \\
\text { et al[2] }\end{array}$ & $\begin{array}{c}\text { María J } \\
\text { Gómora e } \\
\text { tal[11] }\end{array}$ & Our study \\
\hline $\mathrm{AR}$ & $33.3 \%$ & $35.6 \%$ & $54.3 \%$ & $53.1 \%$ \\
\hline $\mathrm{ER}$ & $67 \%$ & $64.4 \%$ & $39.5 \%$ & $82.8 \%$ \\
\hline $\mathrm{PR}$ & $9.3 \%$ & $12.6 \%$ & $49.4 \%$ & $40.6 \%$ \\
\hline
\end{tabular}

\begin{tabular}{|c|c|c|}
\hline $\begin{array}{c}\text { SEX STEROID } \\
\text { HORMONE } \\
\text { RECEPTOR } \\
\text { PROFILE }\end{array}$ & $\begin{array}{c}\text { OVARIAN } \\
\text { CANCER } \\
(\mathrm{n}=64)\end{array}$ & PERCENTAGE \\
\hline $\begin{array}{c}\text { ANDROGEN } \\
\text { RECEPTOR }\end{array}$ & 26 & 40.60 \\
\hline $\begin{array}{c}\text { ESTROGEN } \\
\text { RECEPTOR }\end{array}$ & 53 & 82.80 \\
\hline $\begin{array}{c}\text { PROGESTERON } \\
\text { E RECEPTOR }\end{array}$ & 34 & 53.10 \\
\hline p 53 & 43 & 67.20 \\
\hline WT1 & 45 & 70.30 \\
\hline
\end{tabular}

\begin{tabular}{|c|c|c|c|}
\hline \multirow{2}{*}{$\begin{array}{c}\text { GYNAECOLOGICAL } \\
\text { CANCER } \\
(\mathrm{n}=99)\end{array}$} & \multicolumn{2}{|c|}{ ANDROGEN RECEPTOR } & \multirow{2}{*}{$\mathrm{p}$ value } \\
\cline { 2 - 3 } & PRESENT & ABSENT & \\
\hline ENDOMETRIUM (n=20) & $9(45 \%)$ & $11(55 \%)$ & \\
\hline OVARIAN(n=64) & $26(40.6 \%)$ & $38(59.4 \%)$ & \multirow{2}{*}{$\mathrm{p}=0.78$} \\
\hline $\begin{array}{c}\text { OTHERS(n=15) } \\
\text { (Cervical,sarcoma) }\end{array}$ & $5(33.3 \%)$ & $10(66.7 \%)$ & \\
& & & \\
& & & \\
\hline
\end{tabular}

\begin{tabular}{|c|c|c|}
\hline $\begin{array}{c}\text { GYNAECOLOGICAL } \\
\text { CANCER } \\
(\mathrm{n}=99)\end{array}$ & \multicolumn{2}{|c|}{ ANDROGEN RECEPTOR } \\
\cline { 2 - 3 } & PRESENT & ABSENT \\
\hline ENDOMETRIUM $(\mathrm{n}=20)$ & $9(45 \%)$ & $11(55 \%)$ \\
\hline CERVICAL(n=11) & $1(9.1 \%)$ & $\begin{array}{c}10(90.9 \% \\
)\end{array}$ \\
\hline SARCOMA $(\mathrm{n}=4)$ & $4(100 \%)$ & $0(0 \%)$ \\
\hline OVARIAN $(\mathrm{n}=64)$ & $26(40.6 \%)$ & $\begin{array}{c}38(59.4 \% \\
)\end{array}$ \\
\hline
\end{tabular}

\begin{tabular}{|c|c|c|c|}
\hline $\begin{array}{c}\text { OVARIAN } \\
\text { CANCER } \\
(\mathrm{n}=64)\end{array}$ & \multicolumn{2}{|c|}{ ANDROGEN RECEPTOR } & \multirow{2}{*}{$\mathrm{p}$ value } \\
\cline { 2 - 3 } & PRESENT & ABSENT & \\
\hline $\begin{array}{c}\text { TYPE I } \\
(\mathrm{n}=23)\end{array}$ & $10(43.5 \%)$ & $13(56.5 \%)$ & \multirow{2}{*}{0.72} \\
\hline $\begin{array}{c}\text { TYPE II } \\
(\mathrm{n}=41)\end{array}$ & $16(39 \%)$ & $25(61 \%)$ & \\
\hline
\end{tabular}

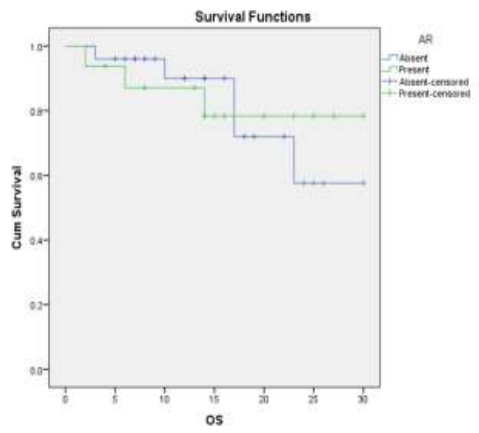

